\title{
Some Notes on Statistics of SWATHs and Catamarans
}

\author{
Victor Dubrovsky \\ Balt Techno Prom Ltd, St. Petersburg, Russian Federation
}

\section{Email address:}

multi-hulls@yandex.ru

\section{To cite this article:}

Victor Dubrovsky. Some Notes on Statistics of SWATHs and Catamarans. Engineering Science. Vol. 4, No. 4, 2019 , pp. 54-58. doi: 10.11648/j.es.20190404.11

Received: July 31, 2019; Accepted: August 29, 2019; Published: December 18, 2019

\begin{abstract}
More or less researched types of multi-hull ships and their specificities: the general view. The main conformity of the ship types and theirs technical and exploitation characteristics. Twin-hulls as most wide- spread types of multi-hulls, especially as high-speed passenger ones. Ship performance as the most important characteristic of fast enough ships. The main dimensions and general characteristics of 25 built twin-hull ships with small water-plane area and 15 built high-speed catamarans. (It is not so big volume for statistics, but even it allows showing of some useful characteristics of these ships.) Some important characteristics of these ships were examined: so named "admiral coefficient; relative speed (Froude number by a hull length); relative length of a hull; relative draft". Calculated relative characteristics show, firstly, evident growth of admiral coefficient of SWATHs with Froude number increasing. Surprisingly, the examined high-speed catamarans have slightly lower admiral coefficient at corresponded Froude numbers, most possible because of smaller immersion of the main volume of hulls and smaller draft, which defines smaller diameter of propulsors. Relative length and relative draft of SWATHs show moderate growth for bigger Froude numbers, but the dispersions are big enough and the usable numbers of these characteristics are not defined more or less exactly. But the better (from propulsion point of view) shown ships can be applied for approximate estimation of the same characteristic of newly designed ships.
\end{abstract}

Keywords: Multi-hulls, Admiral Coefficient, SWATH, Catamaran, Statistics, Relative Dimensions, Relative Draft, Relative Length

\section{Introduction}

General view on multi-hulls. Twin-hull ships as a separate ship type were used periodically since Ancient ages.
For example the first combat steamship was the catamaran "Demologos", Figure 1.

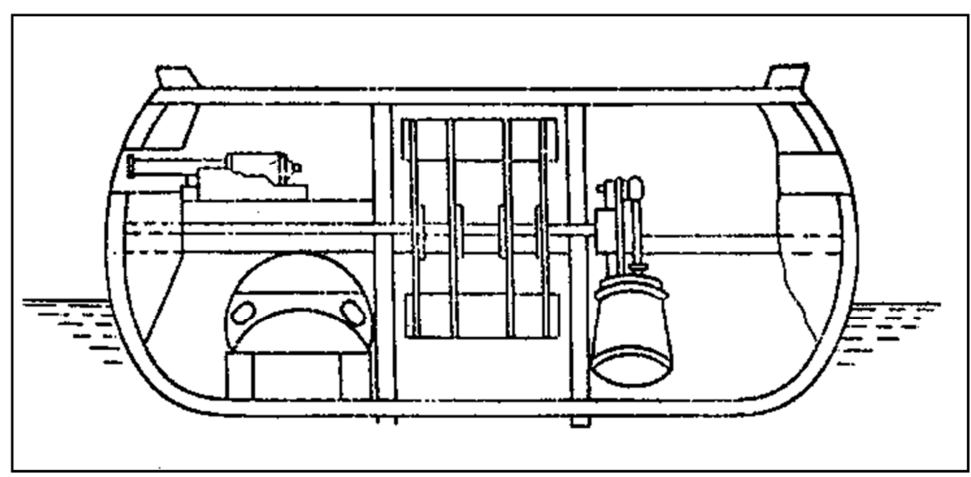

Figure 1. Cross section of the first combat steam ship-catamaran "Demologos" [1].

Most wide application of catamarans of various purposes and wide enough researching of them and of the other multi-hulls began after the World War II. Most wide and detail description of the process is shown by the books [2-5]. 
Today some types of various multi-hulls are researched enough for concept designing without any additional model tests and mass calculations, [6].

Figure 2 shows the researched types of multi-hulls of usual shape of hulls.

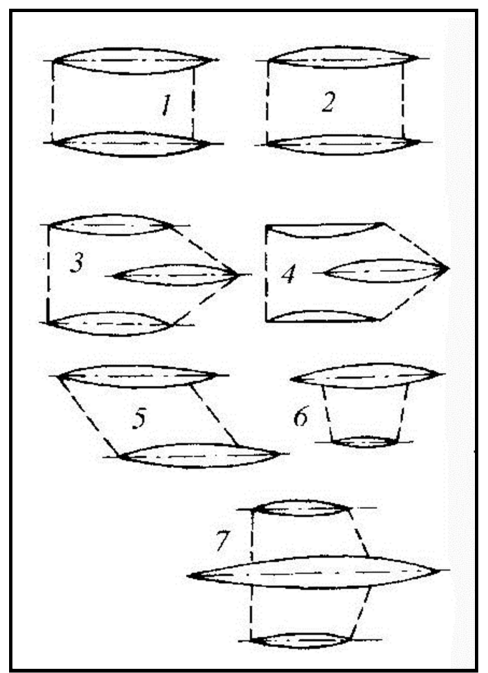

Figure 2. The examined types of usually-shaped multi-hulls.

1,2 - the catamarans with symmetrical and unsymmetrical hulls (the biggest transverse stability); 3,4 - the same trimarans (in Russian terminology), the biggest interaction of wave systems; 5 - a catamaran with shifted hulls (a sum of characteristics of a catamaran and a trimaran); 6 - proa (the minimal mass of the transverse structure); 7 - an outrigger ship (small enough mass of transverse structure).

Figure 3 contains some types of ships with small water-plane area (SWA ships).

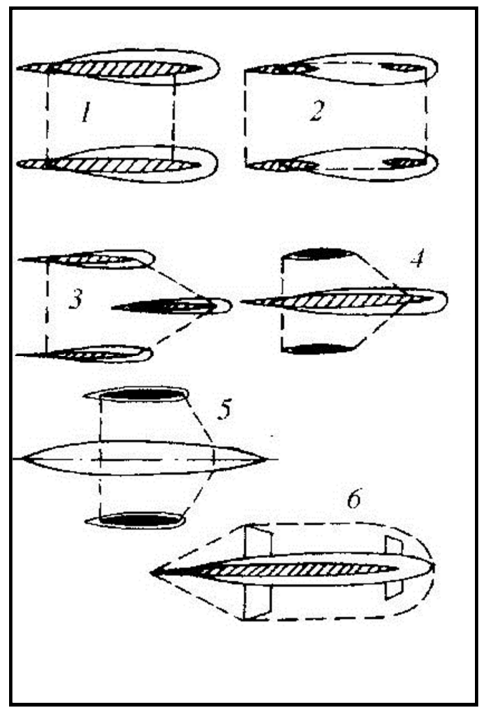

Figure 3. The examined ships with small water-plane area.

1 - a duplus (twin-hull ship with one long strut on each under-water volume, "gondola"), maximal transverse stability of SWA ships; 2 - a trisec (twin-hull ship, two short struts on each gondola) minimal area of water-plane; 3 - a tricore (triple-hull ship of small water-plane area), maximal interaction of wave systems of SWA ships; 4 - an outrigger SWA ship, small enough mass of the transverse structure; 5- a ship with usual main hull and SWA outriggers (option of S. Rudenko); 6 - foiled mono-hull SWA ship, for higher achievable speeds.
Thousands of small-sized catamarans are applied as passenger, tourist, pleasure, and fishery roles;

1. Hundreds of catamarans as fast passenger and car-passenger ferries (today about $70 \%$ of these ferries are catamarans), for example [7];

2. Some catamarans as auxiliary, service, crane ships (for example, [8];

3. Hundreds of semi-submersible rigs for various purposes (for example, [9]);

4. Dozens of small water-plane area ships for full-scale tests and for practical applications, twin-hulls in main, for example, [10-12]);

5. A number of ships with one or two outriggers, including a record sail racer (for example, [13]).

The characteristics of the multi-hulls in use today are briefly examined below.

The relatively larger area of their decks, elimination of the transverse stability problem, reduced roll, the major provision of non-sinkability, and the large aspect ratio of the hulls, all ensure the effective application of catamarans as fast passenger and car-passenger ferries.

Today the special shape of the bow parts of the hulls and the above-water platform ensures the highest level of seakeeping in head waves in the so-called "wave-piercing" catamarans (WPC). Such catamarans are the most effective ferries in terms of contemporary capacity and speed, [14]. Most new multi-hull type is SWATH ("small water-plane area twin hull"). A lot of theoretical, full-scale and experimental data shows that the seaworthiness of a SWATH is approximately the same as that of a mono-hull with a bigger (5-15 times greater) displacement.

The other specificities of SWA ships are the same as those of other multi-hulls: increased area of decks, large volume of the above-water platform, lack of transverse stability problems.

The simple modernization of any mono-hull by adding one or two outriggers allows a substantial increase of capacity (on the decks) and transverse stability, i.e., greater safety of ships employed for various purposes, such as passenger transport or fishery. This modernization can be carried out even without docking the initial ship.

The building of an outrigger battleship is the next important stage of naval fleet development. Such a ship differs from a comparable mono-hull in having a larger area upper deck, greater transverse stability, a larger aspect ratio of the main hull (with the usual shape), and smaller pitch at moderate speeds.

Semi-submersible rigs, as floating objects with a small water-plane area, consist of two or three underwater pontoons that are connected with the above-water platform by a number of struts built in rectangular or circular sections (columns). The design draft is placed at about half of the column height, while the transport draft is placed near the top of the pontoons. Such rigs guarantee all-weather exploitation even in the worst wave and wind conditions.

A separate line of multi-hull development today is researching and building high-speed ships with a small 
water-plane area and twin hulls (SWATH - "ship with small water-plane, twin hull"). A lot of theoretical, full-scale and experimental data shows that the seaworthiness of a SWATH is approximately the same as that of a mono-hull with a bigger (5-15 times greater) displacement.

The other specificities of SWA ships are the same as those of other multi-hulls: increased area of decks, large volume of the above-water lack.

\section{Some Notes on High-speed SWATHs Versus Catamarans}

Evidently, good enough performance is the key characteristic of any high-speed vessels. But good performance must be ensured by the selection of some correlations of dimensions. Some statistical data are examined below.

The book [15] contains the main dimensions and general characteristics of 25 built twin-hull ships with small water-plane area (SWA ships) and 28 built high-speed catamarans. It is not so big volume for statistics, but even the information allows showing some useful characteristics of these ships.
The examined characteristics are:

1. Froude number by a hull length $\mathrm{Fn}=0,515 \mathrm{v}_{\mathrm{S}} /\left(\mathrm{L}^{*} \mathrm{~g}\right)^{1 / 2}$, here $\mathrm{L}$ - hull length, $\mathrm{m}, \mathrm{g}=9,81 \mathrm{~m} / \mathrm{sec}^{2}$;

2. Relative length of a hull $\mathrm{l}_{1}=\mathrm{L} / \mathrm{W}_{1}{ }^{1 / 3}$, here $\mathrm{W}_{1}-$ a hull volume displacement, cu m;

3. Relative draft $\mathrm{d}_{2}=\mathrm{d} / \mathrm{W}_{1}{ }^{1 / 3}$;

4. "Admiral coefficient" $\mathrm{C}_{2}=\mathrm{D}^{1 / 3} \mathrm{v}_{\mathrm{S}} / \mathrm{P}$, here $\mathrm{D}$ - full displacement, $\mathrm{t}, \mathrm{v}_{\mathrm{S}}$ - speed, knots, $\mathrm{P}$ - main engine power, $\mathrm{kWt}$.

5. Relative length as the characteristic of a hull lengthening, as usually, shows the correlation of wave and viscous resistance of a ship.

Bigger draft means bigger immersion of the hull volume and bigger possible diameter of propulsors, i.e. higher propulsive coefficient.

Admiral coefficient shows the total effect of design solutions for performance.

\section{Some Built SWATHs}

Some relative dimensions and characteristics are based on the initial table of the book, see Table 1.

Table 1. Some characteristics of built 25 SWATH

\begin{tabular}{|c|c|c|c|c|c|c|c|c|c|}
\hline \# & Ship name & $\begin{array}{l}\text { Displa - } \\
\text { cement, t }\end{array}$ & Length, m & Speed. Kn & $\begin{array}{l}\text { Power, } \\
\text { kWt }\end{array}$ & $\begin{array}{l}\text { Adm. } \\
\text { Coeffic. }\end{array}$ & $\begin{array}{l}\text { Froude } \\
\text { Numb. }\end{array}$ & $\begin{array}{l}\text { Rel. } \\
\text { Length }\end{array}$ & Rel. draft \\
\hline 1 & "Kaimalino" & 193 & 26.8 & 25 & 3132 & 222.3 & 0.79 & 5.84 & 1.16 \\
\hline 2 & "Marine Ace-1" & 18.4 & 12.3 & 17.3 & 298 & 161.9 & 0.66 & 5.87 & 0.74 \\
\hline 3 & "Marine Ace-1a" & 22.2 & 12.35 & 15.4 & 298 & 129.4 & 0.72 & 5.53 & 0.69 \\
\hline 4 & "Seagull" & 338 & 35.9 & 27.1 & 6040 & 213.3 & 0.74 & 6.49 & 0.57 \\
\hline 5 & "Kotozaki" & 236 & 27 & 20.5 & 2834 & 154.9 & 0.64 & 5.5 & 0.65 \\
\hline 6 & "Ohtori" & 239 & 27 & 20.6 & 2834 & 158.5 & 0.647 & 5.48 & 0.69 \\
\hline 8 & "Charwin" & 193 & 25.3 & 10 & 485 & 91.9 & 0.35 & 5.51 & 0.6 \\
\hline 9 & "Kaiyo" & 2849 & 61.55 & 14.1 & 7400 & 101.4 & 0.29 & 5.47 & 0.56 \\
\hline 10 & "Halcyon" & 52 & 18.3 & 20 & 761 & 195.6 & 0.768 & 5.1 & 0.72 \\
\hline 11 & "Marine Wave" & 19 & 15.1 & 18 & 373 & 148.8 & 0.768 & 7.1 & 0.75 \\
\hline 12 & "Sun Marina" & 19 & 15.05 & 20.5 & 447 & 183.4 & 0.867 & 7.1 & 0.75 \\
\hline 13 & "Chubasco" & 76 & 21.95 & 20 & 1119 & 171.3 & 0.701 & 10.97 & 0.9 \\
\hline 14 & "Frederick G. Creed" & 80.26 & 20.4 & 25 & 1610 & 241 & 0.909 & 5.96 & 0.76 \\
\hline 15 & T-AGOS-19 & 3450 & 71.3 & 10.4 & 3341 & 102 & 0.202 & 5.95 & 0.63 \\
\hline 17 & "Seagull-2" & 350 & 39.3 & 30 & 7882 & 226.9 & 0.786 & 7.03 & 0.58 \\
\hline 18 & FCS 400 "Patria" & 180 & 36.5 & 30 & 4022 & 285 & 0.816 & 8.14 & 0.61 \\
\hline 19 & “Aegian Queen”, design & 1060 & 51.5 & 30 & 14914 & 250 & 0.69 & 6.36 & 0.62 \\
\hline 20 & "Navatek-1" & 365 & 40.24 & 17.5 & 1912 & 191 & 0.45 & 7.09 & 0.65 \\
\hline 21 & “2000 Class" & 80 & 20.43 & 25 & 1610 & 240.6 & 0.91 & 5.97 & 0.76 \\
\hline 22 & "Hibiki" & 3700 & 67.0 & 11 & 2386 & 177.6 & 0.22 & 5.45 & 0.62 \\
\hline 23 & 'T-AGOS-23"' & 5368 & 85.78 & 12 & 3710 & 102 & 0.31 & 5.6 & 0.57 \\
\hline 24 & "Radisson Diamond" & 12000 & 131.2 & 14.15 & 11345 & 174.2 & 0.203 & 7.22 & 0.42 \\
\hline 25 & "Customs 201" & 228 & 35 & 17.5 & 2240 & 119.5 & 0.486 & 7.2 & 0.58 \\
\hline
\end{tabular}

\section{Some Built Catamarans}

Unfortunately, there are the needed data on main dimensions and general characteristics of 15 catamarans only, see Table 2.

Table 2. Some characteristics of built 15 catamarans.

\begin{tabular}{lllllllll}
\hline$\#$ & $\begin{array}{l}\text { Type or name of } \\
\text { craft }\end{array}$ & $\begin{array}{l}\text { Displa - } \\
\text { cement, } \mathbf{t}\end{array}$ & Length, $\mathbf{m}$ & Speed. Kn & $\begin{array}{l}\text { Power, } \\
\text { kWt }\end{array}$ & $\begin{array}{l}\text { Adm. } \\
\text { Coeffic. }\end{array}$ & $\begin{array}{l}\text { Froude } \\
\text { Numb. }\end{array}$ & $\begin{array}{l}\text { Rel. Length } \\
\text { Rel. } \\
\text { draft }\end{array}$ \\
\hline 1 & W86 & 54 & 22.7 & 26 & 1618 & 114 & 0.966 \\
2 & W95 & 74 & 29.3 & 31 & 2646 & 146 & 0.31 \\
\hline
\end{tabular}




\begin{tabular}{llllllllll}
\hline$\#$ & $\begin{array}{l}\text { Type or name of } \\
\text { craft }\end{array}$ & $\begin{array}{l}\text { Displa - } \\
\text { cement, } \mathbf{t}\end{array}$ & Length, $\mathbf{m}$ & Speed. Kn & $\begin{array}{l}\text { Power, } \\
\text { kWt }\end{array}$ & $\begin{array}{l}\text { Adm. } \\
\text { Coeffic. }\end{array}$ & $\begin{array}{l}\text { Froude } \\
\text { Numb. }\end{array}$ & $\begin{array}{l}\text { Rel. Length } \\
\text { Rel. } \\
\text { draft }\end{array}$ \\
\hline 3 & W100 & 84 & 31.7 & 26 & 2646 & 94 & 0.817 & 9.1 & 0.39 \\
4 & W3700SC & 120 & 36.5 & 32 & 4080 & 144 & 0.952 & 9.3 & 0.30 \\
5 & $20 \mathrm{~m}$ & 48 & 18.5 & 24 & 735 & 182 & 0.87 & 6.4 & 0.41 \\
6 & $21 \mathrm{~m}$ & 48 & 19.5 & 25 & 1103 & 137 & 0.88 & 6.76 & 0.44 \\
7 & $22 \mathrm{~m}$ & 55 & 19.5 & 25 & 1176 & 141 & 1.08 & 6.46 & 0.45 \\
8 & $26 \mathrm{~m}$ & 82 & 23.5 & 31 & 1970 & 135 & 0.95 & 6.8 & 0.51 \\
9 & $29 \mathrm{~m}$ & 93 & 25.5 & 26 & 1764 & 150 & 0.79 & 7.1 & 0.39 \\
10 & "Johnson" & 21 & 13.4 & 16.4 & 549 & 71 & 0.73 & 6.1 & - \\
11 & "Shuman" & 36.3 & 18.3 & 24.2 & 1020 & 178 & 0.93 & 6.96 & 0.25 \\
12 & "Double eagle" & 29.5 & 19.8 & 21.2 & 240 & 166 & 0.82 & 7.46 & 0.26 \\
13 & "Double eagle II" & 28.4 & 19.8 & 23.4 & 800 & 174 & 0.91 & 7.36 & 0.23 \\
14 & "Rainbow II" & 37.5 & 18.9 & 20.8 & 800 & 147 & 0.79 & 7.1 & 0.28 \\
15 & "H\&M Speed Two" & 40.9 & 18.3 & 24 & 800 & 120 & 0.77 & 6.7 & 0.27 \\
\hline
\end{tabular}

\section{Relative Dimensions Versus Froude Number}

As usually, bigger relative length of a hull $\left(1=\mathrm{L} / \mathrm{V}_{1}{ }^{1 / 3}\right)$ means smaller wave resistance and bigger wetted area, i.e. bigger viscous resistance. Figure 4 contains the dependence of the relative length from Froude number by the length of a hull.

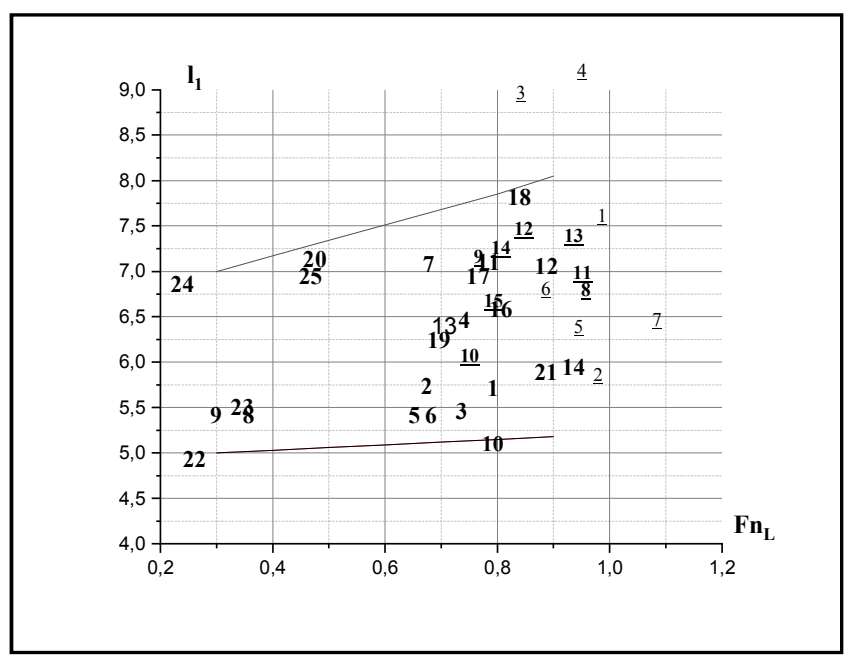

Figure 4. Relative length of a hull $l=L / V_{l}^{I / 3}$ vs. Froude number by a hull length FnL (upper and lower values of SWATHs are approximately shown by lines, not marked numbers correspond to Table 1, italic numbers correspond to catamaran data).

Evidently, the dispersion of the points is big enough, than a definite trend is not notable. But in main the relative length slightly growths for bigger Froude numbers.

Evidently, the examined catamarans have approximately the same relative length of a hull.

Bigger relative draft means bigger immersion of the main displaced volume of small water-plane hull, and, therefore, smaller wave resistance, but bigger wetted area, i.e. bigger viscous resistance. Besides, bigger draft means the possibility of bigger diameter of propellers, i.e. higher propulsive coefficient usually.

The Figure 5 shows the comparison of relative draft of the examined ships $\mathrm{d} / \mathrm{V}_{1}{ }^{1 / 3}$ versus Froude number.

Evidently, the dispersion is big enough, but small trend of growth for bigger Froude numbers can be noted. And the values of catamaran hull relative draft are evidently lower ones, than of SWA ships.

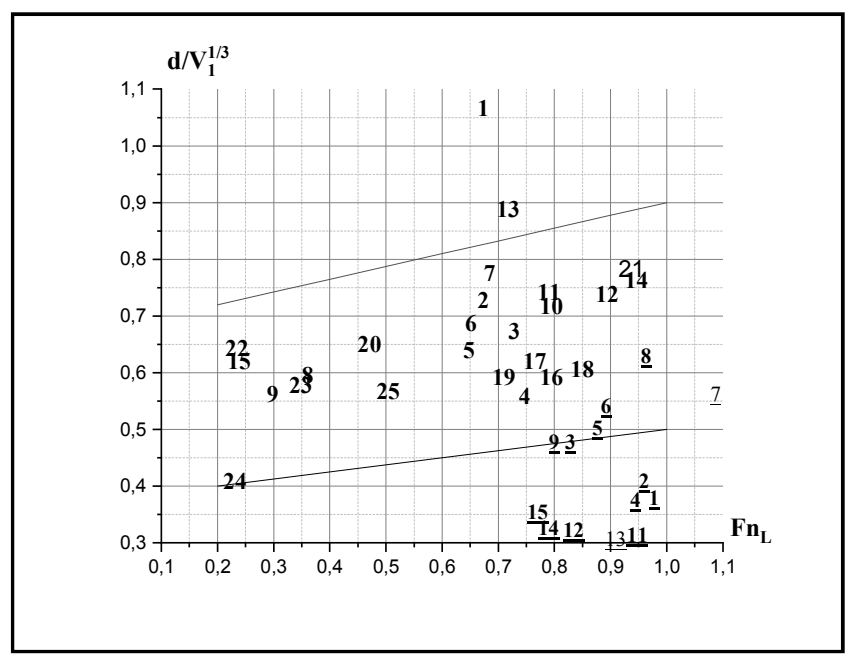

Figure 5. Relative draft $d / V_{I}^{1 / 3}$ versus Froude number $F n_{L}$ (upper and lower values of SWATHs shown approximately by lines, usual numbers correspond to Table 1, italic ones - to Table 2).

\section{Performance Characteristic}

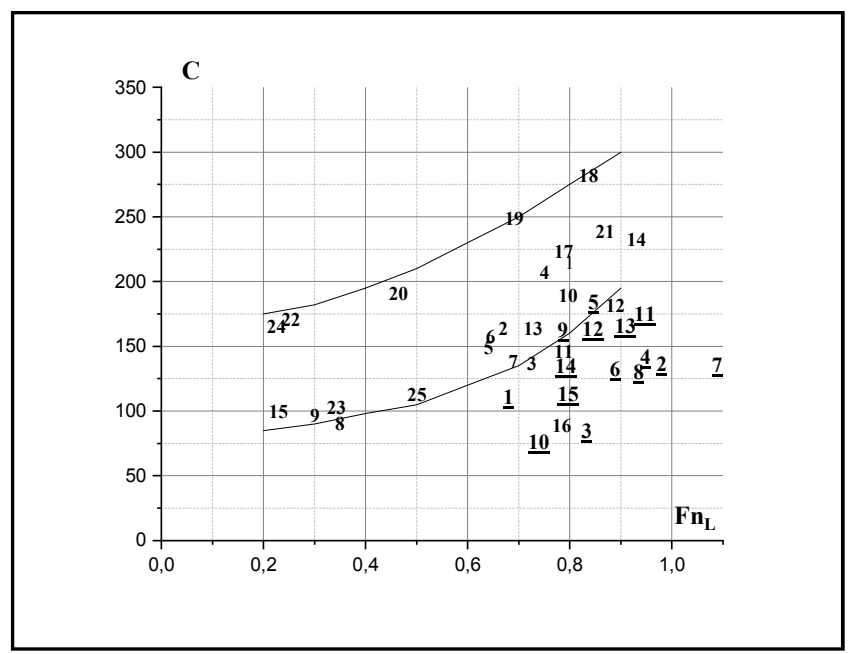

Figure 6. Admiral coefficient $C=W^{2 / 3} v_{S}{ }^{3} / P$ vs. Froude number (the biggest and smallest values of $S W A T H$ s are shown by lines, usual numbers correspond to Table 1, underlined ones - to Table 2). 
So named "admiral coefficient" C, see previously definitions, is one from possible characteristic of a ship performance. Figure 6 contains such coefficient versus Froude number by length Fn.

In spite of big enough dispersion, growth of $\mathrm{C}$ of SWA ships with Froude number growth seems evident. It is a very interesting fact, because corresponded coefficient of traditional mono-hulls drops with growth of Froude number by hull length.

\section{Discussion}

The values of admiral coefficient of the examined catamarans in general are smaller, than of SWA ships. It can be supposed, it is the main result of bigger immersion of the main displaced volume of SWA ships and bigger diameter of theirs propulsors.

\section{Conclusions}

i. Relative length of the examined SWATHs and catamarans can be approximately the same.

ii. Relative drafts of the examined catamarans are in main smaller, than of the examined SWATHs.

iii. Admiral coefficient of the examined SWATHs is bigger, than of the examined catamarans, especially at high enough Froude numbers.

\section{Recommendation}

The shown dependencies can be applied for early stages of performance estimation of the twin-hull ships with small water-plane area and high-speed catamarans.

\section{References}

[1] Virginskiy, V. "Robert Fulton”, 1965, Nauka Publishing House, 123 p., in Russian.
[2] Dubrovsky V., Lyakhovitsky A., "Multi-hull ships". 2001, ISBN 0-9644311-2-2, Backbone Publishing Co., Fair Lawn, USA, $495 \mathrm{p}$.

[3] Dubrovsky V., "Ships with outriggers", 2004, ISBN 0-9742019-0-1, Backbone Publishing Co., Fair Lawn, USA, 88 p.

[4] Dubrovsky V., Matveev K., Sutulo S, "Ships with small water-plane area", 2007.

[5] Dubrovsky V. "Specificity and designing of multi-hull ships and boats", 2016, Nova Science Publishers, ISBN 9781634846158, USA, $210 \mathrm{p}$.

[6] Dubrovsky V, "Minimal-Sized Ships with Small Water-Plane Area”, 2013, Journal of ocean, mechanical \& aerospace science \& engineering, December, vol. 2, pp. 1-5.

[7] "New Water-Jet-Powered Catamaran Ferry", 1979, Naval Architect, Apr., p 135.

[8] Gubanov, V, "Crane Catamaran "Ker-Ogly"'. Shipbuilding, 1968, No. 8, p3-10, in Russian.

[9] "New drilling rig", Ocean Industry, 1977, vol. 12, \#11, pp. 122-127.

[10] "New drilling ship", Holland Shipbuilding, 1970, vol. 18, \#10, pp. 52-57.

[11] "Mammoth pipe-lying barge for North Sea", Naval Architect, 1975, \#4, p. 132-137.

[12] Kennell C., "SWATH ship design trends", International conference on SWATH ships and advanced multi-hull vessels, 1992, April, pap. 2, 16 p.

[13] "Independence class littoral combat ships", www.MilitaryToday.com.

[14] "Wave-piercing catamarans", www.incat.com.au.

[15] Liang Yun, Alan Bliault, Huan Zong Rong," High-speed catamarans and multi-hulls", 2016, Springer Publishing house. 